\title{
Ultrastructure of Lejeunea spp. leaves surface in a lowland tropical urban forest of Universitas Indonesia Campus, Depok, Indonesia
}

\author{
AFIATRY PUTRIKA, DHITA MUTIARA NABELLA, ANDI SALAMAH, NISYAWATI, ASTARI DWIRANTI \\ Department of Biology, Faculty of Mathematics and Natural Sciences, Universitas Indonesia. Jl. Lingkar UI, E Building UI Campus, Depok 16242, West \\ Java, Indonesia. Tel.: +62-21-7270163, Fax.: +62-21-78829010, `email: astari.dwiranti@ sci.ui.ac.id
}

Manuscript received: 18 June 2020. Revision accepted: 19 August 2020.

\begin{abstract}
Putrika A, Nabella DM, Salamah A, Nisyawati, Dwiranti A. 2020. Ultrastructure of Lejeunea spp. leaves surface in a lowland tropical urban forest of Universitas Indonesia Campus, Depok, Indonesia. Biodiversitas 21: 4184-4191. Lejeunea is one of liverworts genera that have a wide distribution in the world. It has many variations of the character that have not been revealed, such as variations of the cell surface. The purpose of this research was to study the ultrastructure of Lejeunea spp. leaves surface in a lowland tropical urban forest of Universitas Indonesia (UI) Campus, Depok, Indonesia. Six species of Lejeunea spp. were studied, i.e., L. anisophylla, L. cocoes, $L$. exilis, L. papilionacea, L. catanduana, and L. curviloba. The research methods carried out in this study consisted of the sample observation using a light microscope, sample preparation for Scanning Electron Microscope (SEM) observation (fixation, post-fixation, dehydration, drying, mounting), and observations using SEM. The results of observation using a light microscope showed the smooth cell surface of all samples studied. Meanwhile, the differences between six species of Lejeunea in the UI campus could be differentiated under SEM. $L$. catanduana could be distinguished from other species from its cell wall thickness and texture, ornamentation types, and the number of ornamentations per cell. The texture of the cell wall of L. catanduana was the roughest than the other species due to abundant ornamentation such as papillae on its the cell wall surface. Furthermore, only this species has mamillae on the cell surface. The number of papillae or mamillae was 1-4 per cell. On the other hand, L. cocoes has the thinnest cell wall and slightly rough texture. Only this species has the simple papillae on the cell surface. Thus, the results of this study suggested that the cell surface variations in Lejeunea might be potential to be used as taxonomic characters in grouping species.
\end{abstract}

Keywords: Leaf cell surface, Lejeunea, light microscope, scanning electron microscope, ultrastructure

\section{INTRODUCTION}

Leafy liverwort is a type of liverworts that has a widespread distribution, especially in tropical areas (Konrat et al. 2008). This group has a leaf-like structure, which is not possessed by the thallus-shaped liverworts (Gradstein 2011). One of the largest families found in leafy liverwort is Lejeuneaceae. The distribution of Lejeuneaceae is around $50-90 \%$ in the African, Australian, and IndoMalayan regions. The largest genus in the family Lejeuneaceae is Lejeunea Lib., that spread mainly in tropical Asia. The genus has about 150-200 species (Lee and Gradstein 2013). Lejeunea is one of liverworts genera that have a wide distribution. In Indonesia, the presence of Lejeunea spp. was reported 5 species in Central Java (Haerida and Gradstein 2011), 2 species in Bali (Haerida 2017), 3 species Mount Patuha (Gradstein et al. 2010), and also in the Universitas Indonesia (UI) (Ariyananda 2015; Wijaya et al. 2019; Putrika et al. 2020). The previous study reported there are six species of Lejeunea found in the Universitas Indonesia campus, which identified as $L$. anisophylla Mont, L. cocoes Mitt, L. exilis (Reinw., Blume \& Nees) Grolle, L. papilionacea Prantl (Wijaya et al. 2019; Putrika et al. 2020), L. catanduana (Steph.) H.A. Mill., H. Whittier \& B. Whittier, and L. curviloba Setph. (Ariyananda 2015). These species were identified morphologically by using a light microscope based on the lobule, lobes, underleaves, oil bodies, etc. Although these six species have been identified, they have character similarities in terms of morphology, which are sometimes not easily distinguished amongst them, especially between L. cocoes and $L$. exilis, such as leave arrangement, lobes and lobule shape, cell shape, and oil body type (Putrika et al. 2020).

Species belongs to the genus Lejeunea have many variations of the character that could never see under a light microscope due to the limitation in resolution and magnification. One of the characters is variations of the cell surface (Lee et al. 2011), which could make different species misinterpreted into similar species. Wax ornamentation is one character of variation in leaf cell surfaces that can help to identify Lejeunea at the species level. Ornaments in each species have a unique shape, such as the presence of papillae in various sizes and numbers, as reported by Lee et al. (2014), who found L. mimula and $L$. tuberculosa have ornaments that are relatively small in size and spread throughout the cell surface. Therefore, ultrastructure such as wax ornamentation becomes a stable character in a species that can be used to help in the identification of Lejeunea. Ultrastructure means the fine structure, especially within a cell, that can be seen only with the high magnification obtainable with an electron microscope. The ornamentation would be clearly identified using the high-resolution electron microscope. The scanning electron microscope is a high-resolution microscope enabling visualization up to nanometers level 
with the magnification reaches 3,000,000 times (Choudhary and Priyanka 2017).

The ultrastructure of 31 species of leafy liverworts, especially Lejeunea in Asia was reported by Lee et al. (2014). In addition, Lee (2020) also showed the ultrastructure of 24 Lejeunea species in Malesian region. However, to date, the ultrastructure characters of Lejeunea spp. in Indonesia, particularly in Universitas Indonesia Campus, Depok, West Java, Indonesia has not been reported. Universitas Indonesia (UI), which is located in the urban area, has a vast open green space area, such as an urban forest and campus green park. This location has numerous species of Bryophyte which are adapted in the urban environment. The morphological identification of Bryophyte, including the genus of Lejeunea in UI has been carried out previously. Thus, this study aimed to describe the ultrastructure cell surface variance of six species of Lejeunea. The results of this study gave an insight into the ultrastructure variations of different Lejeunea species and further reinforce the possibility of using the ultrastructure characteristic for species identification, especially for those with similar characteristics.

\section{MATERIALS AND METHODS}

\section{Study area}

Six species of Lejeunea were taken from the Universitas Indonesia (UI) campus area of Depok, West Java, Indonesia (Figure 1). The sample collection was conducted from January until June 2019. This research evaluated 4 species of fresh specimens and 2 species of herbarium specimens. Four fresh specimens were collected from the campus main street area, according to Putrika et al. (2019) sampling sites. Meanwhile, the two herbarium samples were collected in UI Urban Forest (Ariyananda 2015). Each species consisted of 3 samples which have been observed with Scanning Electron Microscope (SEM). The sample preparation process was carried out at Integrated Laboratory Research Center (ILRC) Universitas Indonesia. The SEM was observed in the PUSPIPTEK BPPT Serpong, Tangerang Selatan, Indonesia.

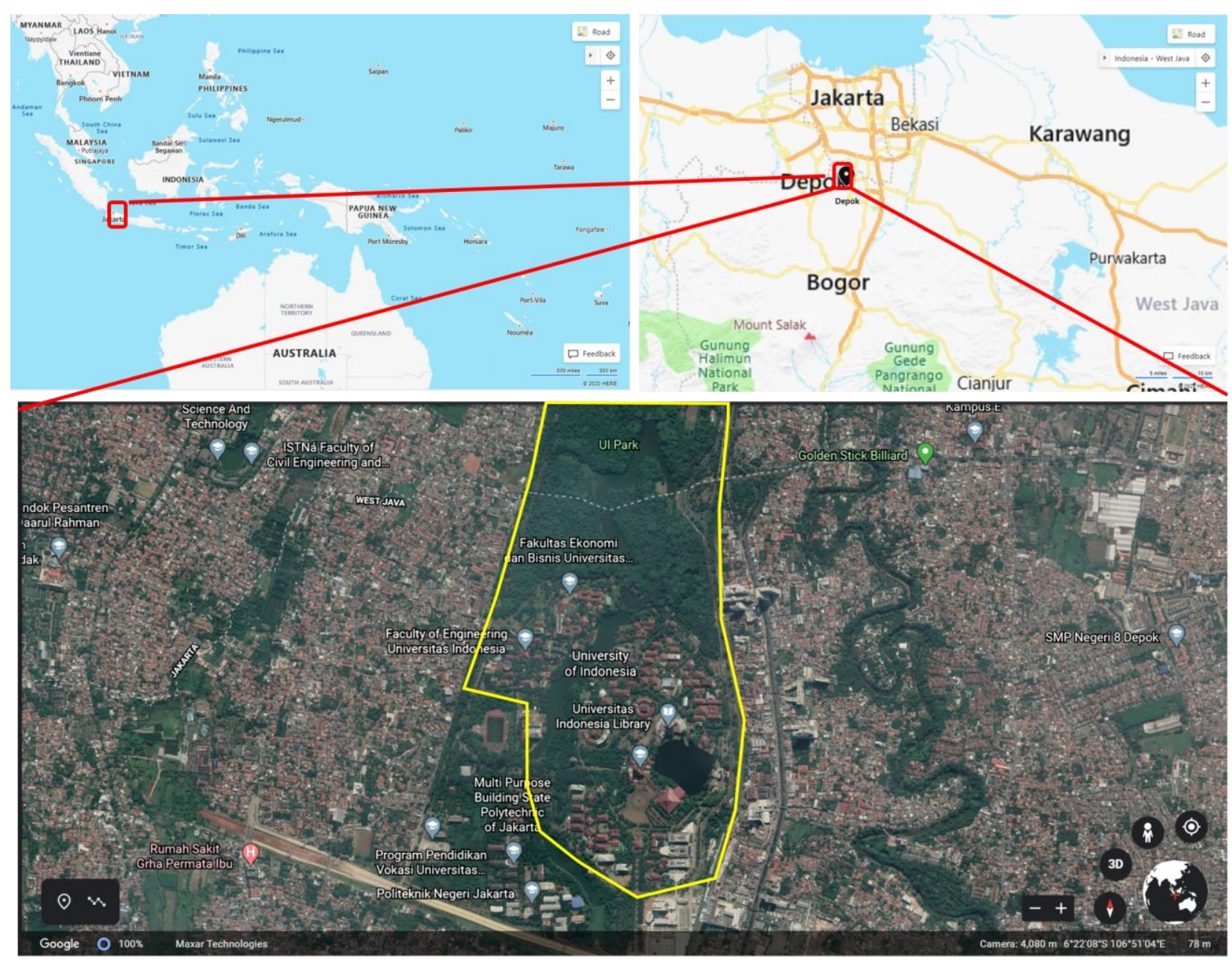

Figure 1. The area of Universitas Indonesia, Depok, West Java, Indonesia. The yellow line indicates the sampling site in this study and reported by Putrika et al. (2020). (source: google earth) 


\section{Procedure}

The samples obtained from the field were observed using a stereomicroscope and an inverted microscope to ensure that the species taken belongs to the genus of Lejeunea. Lobe, lobule, margin leaf cell, and laminal cell shape were observed using a light microscope (Ariyananda 2015; Putrika et al. 2017). Samples that have been observed using a light microscope were then placed in a petri dish for SEM preparation. Sample preparation for observation using SEM consists of five main steps, i.e. fixation, post-fixation, dehydration, drying, and mounting. Samples were fixed using $2.5 \%$ glutaraldehyde in PBS $(\mathrm{pH}$ 7.0) for 30 minutes. Then the washing step was carried out using Phosphate Buffer Saline (PBS) three times, 10 minutes each. After the fixation, samples were then subjected to the post-fixation using a solution of $4 \% \mathrm{OsO}_{4}$ in PBS for 15 minutes and followed with PBS washing. Samples were then dehydrated using ethanol series $(70 \%$, $80 \%, 90 \%, 100 \%$ ), and dried using hexamethyldisilazane (HMDS) (Dwiranti et al. 2019). The samples were finally mounted and observed using SEM.

\section{Data analysis}

Quantitative analysis was carried out using ImageJ software. The scale of the system was set according to the scale bar taken from the microscope. After that, by using line, the width and length of a specific area of interest were measured. The width and length appeared were derived automatically from the software using the set scale.

\section{RESULTS AND DISCUSSION}

There are four species of Lejeunea found in the study area, i.e. L. cocoes, L. anisophylla, L. papilionacea, and $L$. exilis. Another two species, L. catanduana and L.curviloba, which were reported by Ariyananda (2015), could not be found in this study. Nevertheless, Zhu et al. (2018) informed that $L$. anisophylla is accepted name, and placed $L$. catanduana as synonymous. Thus, in this study there are 2 samples of $L$. anisophylla, one specimen is a fresh material and another specimen is a dry herbarium collection from 2014. The herbarium collection of L. anisophylla, which has been identified as L. curviloba, was collected in the campus urban forest. It is found in the shaded area than the main street study site. To complete the ultrastructure data of all species formerly found in Universitas Indonesia, the two herbarium collections were observed. The fresh specimens have a green color, meanwhile, the herbarium specimen showed brown color under the light microscope. Both fresh specimens and herbarium specimen have a clear and detailed surface structure visualized by SEM. In general, those species can be distinguished by the lobes, lobule, and underleaves, using light microscopy. The detailed ultrastructure such as ornamentation of the leaf surface could only be visualized using SEM.

\section{Leaf morphology of Lejeunea spp.}

Lejeunea leave is divided into large dorsal lobes and small ventral lobule. Figure 2 shows the variation of leaf arrangement and leaf lobes shape of six species of Lejeunea. L.exilis and L. cocoes have a similar character, such as distant of leaf arrangement, minute size and caducous leaves, as well as obtuse leaf apex (Figure 2). According to those characters, L. exilis sometimes interchangeably with $L$. cocoes. Lee et al. (2014) revealed that $L$. exilis and $L$. cocoes are closely related according to the phenetic analysis. Both species can be distinguished by the perianth character, leaf cell, and underleaves shape (Lee 2013).

Based on the light microscope observation, $L$. anisophylla, L. papilionacea, $L$. curviloba, and $L$. catanduana have a dense leaf arrangement. The leaf shape of L. anisophylla, L. cocoes, and L. exilis are ovate. $L$. papilionacea, L. catanduana, and L. curviloba have oblong-rectangular lobes. The lobes leaf apex of $L$. cocoes and $L$. exilis is obtuse but the other species showed round shape. Those characters in Figure 2 were visualized clearly using a light microscope and SEM. Even though $L$. anisophylla and L. catanduana are the same species, in this study, they showed the different lobes shape. These differences might be caused by a different point of view. The fresh L. anisophylla was observed form the middle site of one individual, meanwhile, L. anisophylla, previously known as L. catanduana, taken from the herbarium specimen, was observed from the apical side (Figure 2).

The lobule of Lejeunea was observed under light microscopy and SEM (Figure 3). There are four species that can be observed clearly under light microscopy and SEM, i.e. L. anisophylla, L. cocoes, L. exilis, and $L$. papilionacea. Meanwhile, lobule of $L$. catanduana and $L$. curviloba were only seen obviously under SEM. It may be because those two species are the dry herbarium specimen, so that it has brownish color in the light microscope. According to the SEM imaging, a specific character found in all Lejeunea observed is a single teeth lobule. Lee (2013) reported that single teeth lobule is a distinguishable character of Lejeunea from other genera within the Lejeuneaceae family. The leaf lobule of $L$. anisophylla, $L$. cocoes, L.exilis, and L. papilionacea have a truncate apex. The two herbarium specimens, L. catanduana and L.curviloba have a rounded lobule apex.

\section{Margin leaf cell}

According to the light microscope observation, the leaf lobes margin of L. papilionacea is crenulate, while the other species has the entire margin cells. The margin lobes cells of $L$. papilionacea are more swollen than other cells, thus it makes the leaf margin crenulate. Moreover, the leaf margin of L. papilionacea seems to have a border because of different cell shapes and sizes in the leaf lobes margin. The leaf margin of L. anisophylla, L. exilis, and L. cocoes is entire. They have pentagonal shapes and the sizes of the leaf margin are smaller than the other cells. Two specimens from the herbarium sample, $L$. catanduana and $L$. curviloba, have a clear shape of the margin cell visualized by SEM. The leaf margin cells of L. catanduana have a smaller size than in the middle cells (Figure 4). The border of each cell was distinguishable and indicated by "br" within the figure. 


\section{Laminal cell}

The observation using a light microscope shows that all species of Lejeunea relatively similar surface without any up-and-down structure. A light microscope could facilitate the observation of the sample two-dimensionally, thus no detailed ornamentation or three-dimensional structure was visualized by using a light microscope. The median leaf cells of six species of Lejeunea have a pentagonalhexagonal shape based on the light microscope observation. The cell shapes of six species of Lejeunea are more detailed under SEM (Figure 5). Figure 5 B' shows that $L$. cocoes has shrinkage leaf cells because of a smaller size than the other species and the thinnest cell walls (Table 1), therefore it is more easily shrank. From the light microscope visualization, $L$. cocoes cells are not shrunk. The cell shape of the species is hexagonal that can observe clearly under a light microscope. The visualization of the median leaf cells from herbarium specimens also showed a clear structure. There was no shrinkage of the cells. The observation of herbarium specimens also shows some ornamentations on the leaf's cell surface which could not be observed under the light microscope.

The observation of six species Lejeunea under SEM shows that each species has a variety of size, number, and type of ornamentations on the lamina cells (Table 1). SEM imaging shows that the lamina cell surfaces are not completely smooth (Figure 6). There are two types of ornamentations such as papillae and mammillae on some parts of the cell surfaces. Among all species, L. catanduana shows the roughest texture of the lamina cells. This species has two types of ornamentations, i.e. conical papillae and mamillae which are spread almost all over the cell surface. Furthermore, this species has the largest size of ornamentations compared to the others. L. cocoes, $L$. anisophylla, L. papilionacea, and L.curviloba only has one type of ornamentation and it is not spread on all part of the cell surface. Table 1 shows that the ornamentation type of L. cocoes has conical papillae in the leaf cell surface, while the other has conical papillae. Lee et al. (2013) show that most Lejeunea has a smooth leaf surface or slightly rough with minute papillae. L. papilionacea, L. exilis, and Lejeunea cocoes in Malaysia have been reported that they have a smooth leaf cell surface (Lee 2020).

Under a light microscope, L. cocoes and L. exilis are look-alike and sometimes are difficult to be distinguished. However, herewith we show that both species could be differentiated clearly under SEM due to the different dominant forms of papillae. L. cocoes has simple papillae, and L. exilis has a conical papilla (Table 1). This character could not be found in L. cocoes and Lexilis in Malaysia (Lee 2020). This difference might be induced by the different preparation methods for SEM observation. Lee (2020) prepared the sample using the critical point drying method, while in this study, the samples were dried by using Hexamethyldisilazane (HMDS) following Dwiranti et al. (2019).
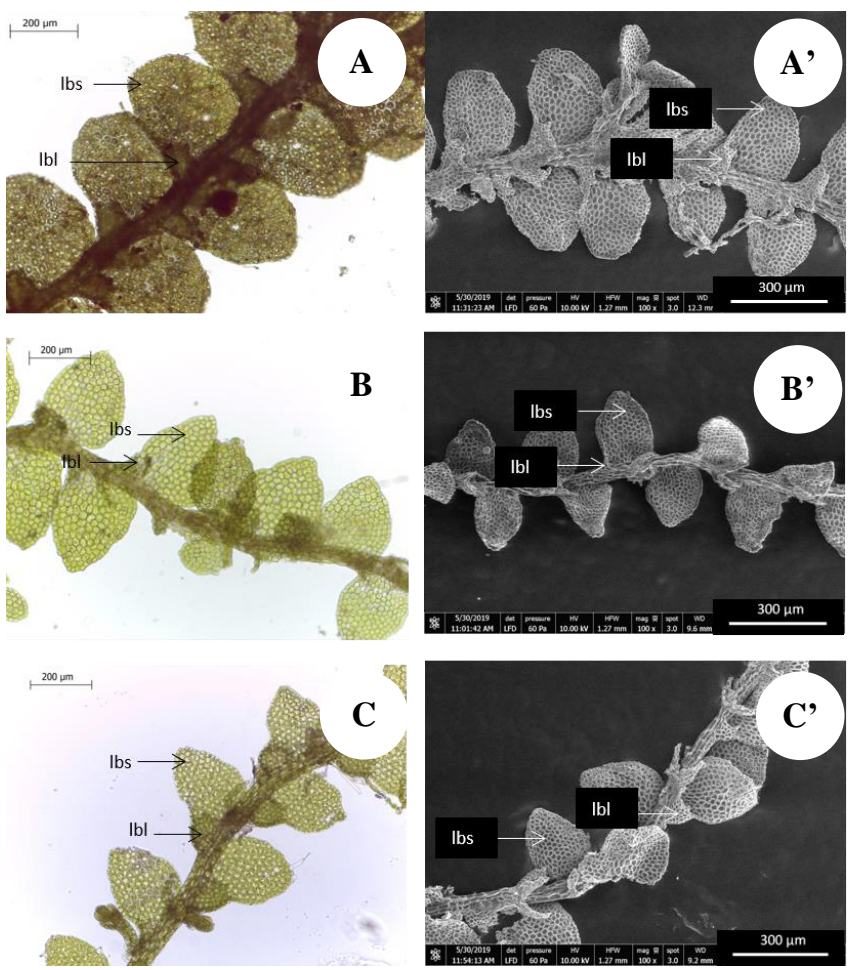
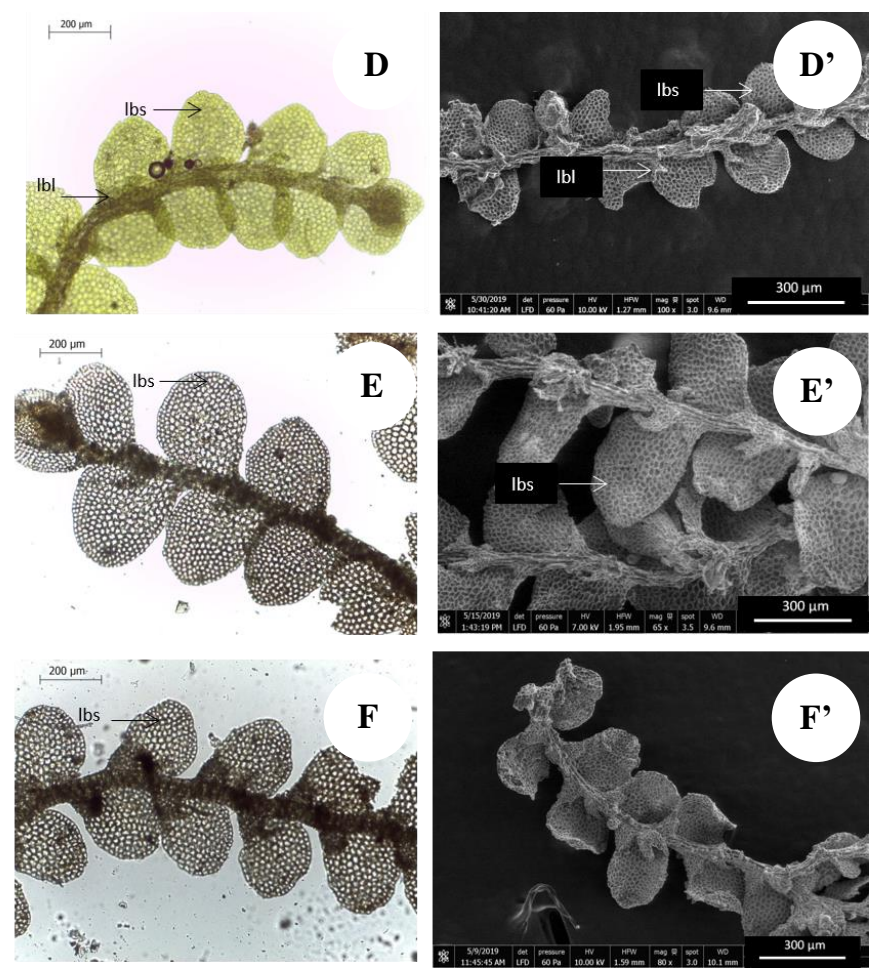

Figure 2. Visualization of Lejeunea spp. leaf arrangement and lobes. L. anisophylla (A, A'), L. cocoes (B, B'), L. exilis (C, C'), L. papilionacea (D, D'), L. catanduana (E, E') and L. curviloba (F, F') observed by light microscope (A-F) and SEM (A'-F'). Samples AD were freshly prepared, while E and F were taken from the herbarium. "lbl" showed the lobule and "lbs" showed the lobes. 

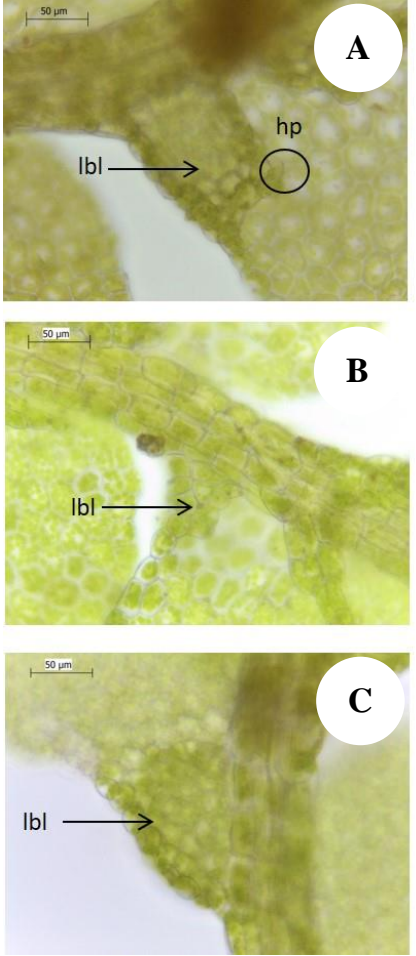
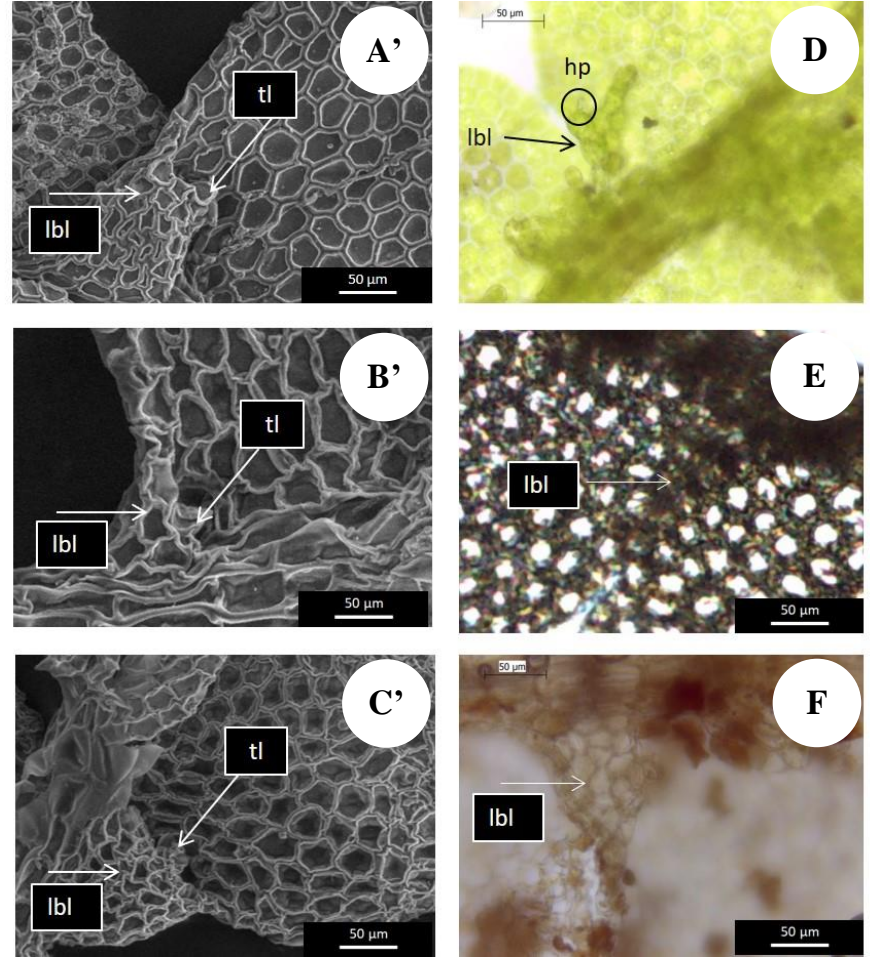
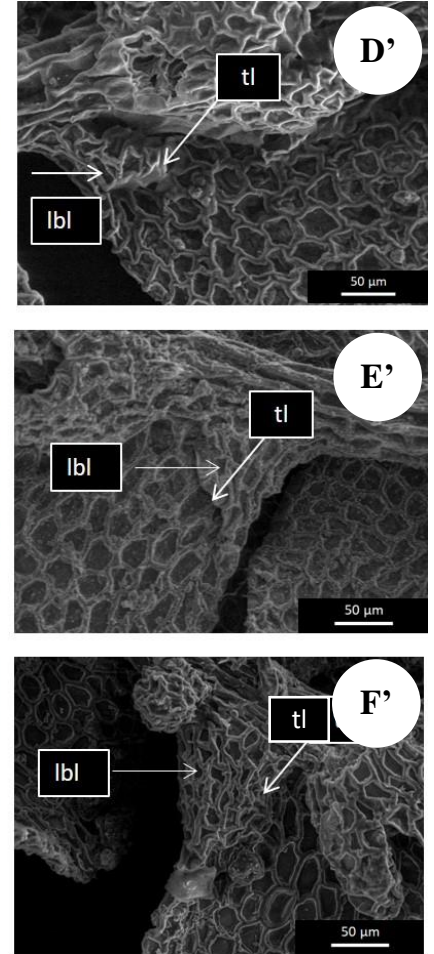

Figure 3. Visualization of Lejeunea spp. lobule. L. anisophylla (A, A'), L. cocoes (B, B'), L. exilis (C, C'), L. papilionacea (D, D'), L. catanduana (E, E') and L. curviloba (F, F') observed by light microscope (A-F) and SEM (A'-F'). Samples A-D were freshly prepared, while E and F were taken from the herbarium. "lbl" showed the lobule. "hp" showed the hyaline papillae. "tl" showed the teeth lobule
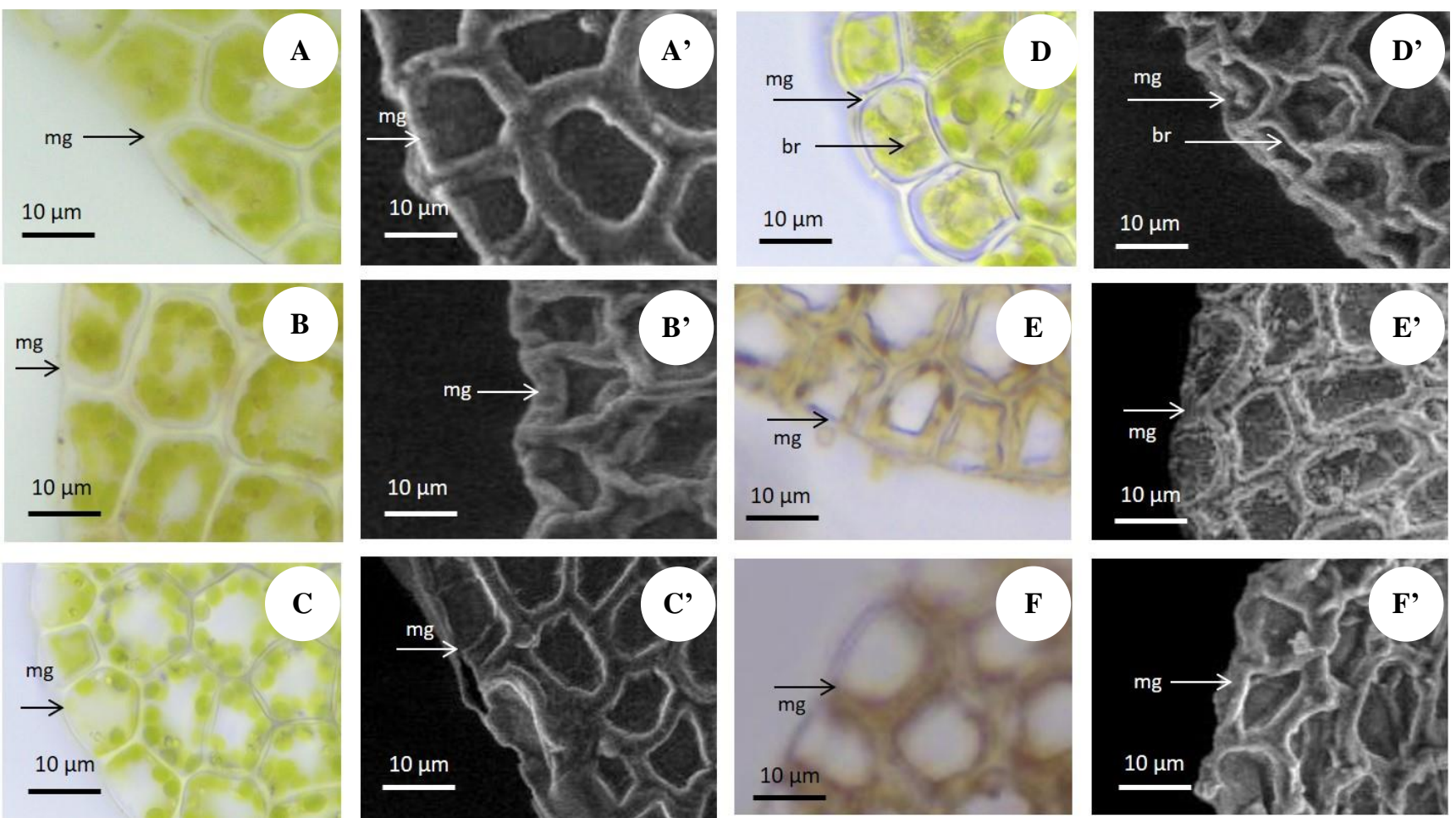

Figure 4. Visualization of Lejeunea spp. margin leaf cell. L. anisophylla (A, A'), L. cocoes (B, B'), L. exilis (C, C'), L. papilionacea (D, D'), L. catanduana (E, E') and L. curviloba (F, F') observed by light microscope (A-F) and SEM (A'-F'). Samples A-D were freshly prepared, while $\mathrm{E}$ and $\mathrm{F}$ were taken from the herbarium. "mg" indicates the margin. "br" indicates the border 

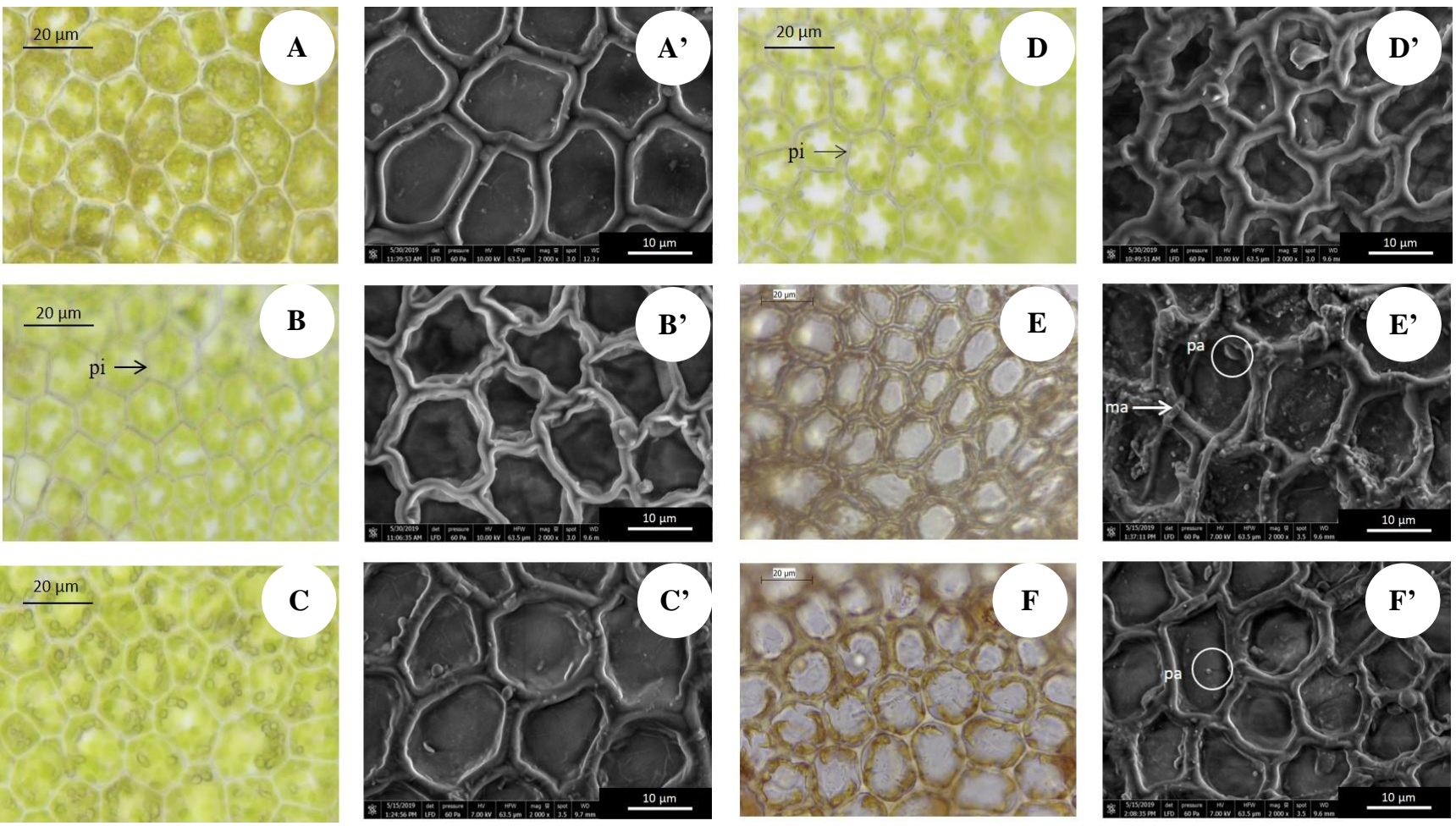

Figure 5. Visualization of the Laminal cell shape variation of Lejeunea spp. L. anisophylla (A, A'), L. cocoes (B, B'), L. exilis (C, C'), L. papilionacea (D, D'), L. catanduana (E, E') and L. curviloba (F, F') observed by light microscope (A-F) and SEM (A'-F'). Samples A-D were freshly prepared, while E and F were taken from the herbarium. "pa" indicates papillae, while "ma" indicates mamillae. "pi" depicted the intermediate thickening.

The papillae character was also found in true mosses carried out by Câmara and Kellogg (2010) in the family of Pottiaceae, Fissidentaceae, Rachitheciaceae, and Sematophyllaceae with varying forms, namely the cone shape and baggy shape. The function of papillae in mosses is still unclear, nevertheless previous study proposed that it has a role to regulate light and temperature for adaptation to xerophyte conditions (Câmara and Kellogg2010).

Mamillae-shaped cell surface ornamentation is only found in $L$. catanduana. The shape of the mamillae of $L$. catanduana is almost the same as the shape of the mamillae in the species Gymnostomum calcareum which has an elongated shape like a rope (Kou et al. 2014). Even though Lejeunea catanduana is a synonym of $L$. anisophylla, in this study, they have a different character in the leave cell surface. L.catanduana has a rough surface with abundant conical papillae and mamillae on the cell surface. It also has a thick cell wall and has ornamentations in the cell wall surface (Figure 6E). On the other hand, L. anisophylla has a slightly rough surface with only conical papilla. It might be because those samples were collected from different site conditions. Further study with more sample collection from a different location would be necessary. $L$. catanduana is the most distinguishable compared to other species according to the type and number of cell surface ornamentation.
Lejeunea cocoes has the thinnest cell wall and slightly rough texture. Only this species has simple papillae on the cell surface (Table 1). According to Lee (2013), L. cocoes has a hyaline cell wall, thus it might be the reason for the thin cell walls. $L$. cocoes in Malaysia have been reported to have a smooth leaf cell surface (Lee 2020). The different result might be because of the different habitat conditions between Malaysia and Indonesia, especially Depok. These results indicated the use of ultrastructure would be beneficial for species identification. Further evaluation would be necessary to confirm this, especially regarding the adaptation mechanism that could induce ultrastructure differentiation. The larger number of species within the same genus from a different location with different environmental parameters would thus be necessary.

Another information that could be retrieved from the ultrastructure observation using SEM is the trigon. According to SEM observation, it is clear that all species have the trigons. L. anisophylla, L. cocoes, L. papilionacea, $L$. catanduana have large trigon, meanwhile, L.exilis and $L$. curviloba have small trigon (Figure 7). Siregar et al. (2020) reported that $L$. curviloba has an indistinct trigon as well. These results suggested that trigon development could also be used to differentiate one species from the other. This result is consistent with those reported by Lee (2013) that stated that trigon could be used to differentiate the species. 

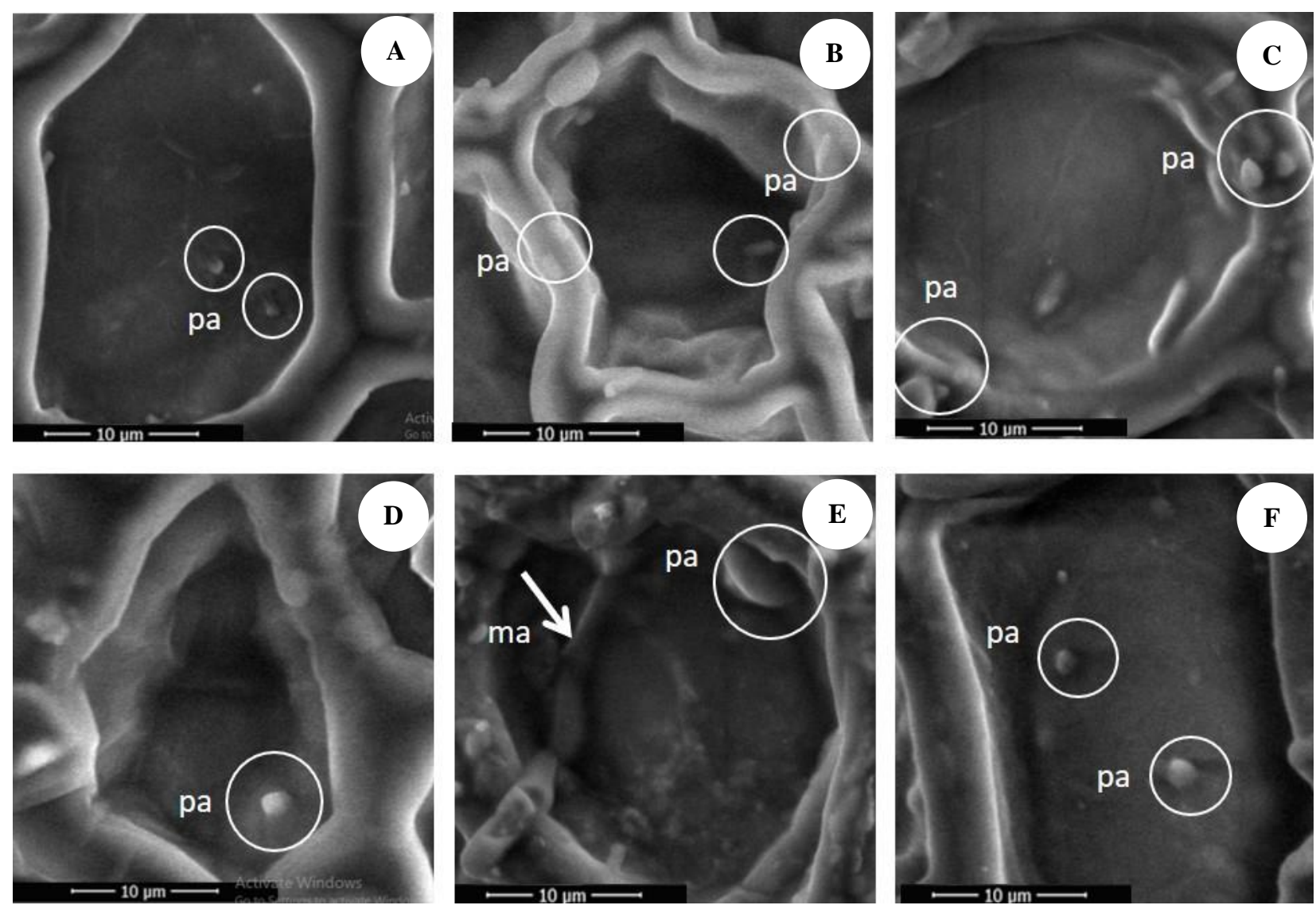

Figure 6. Visualization of the laminal cell surface ornamentation of Lejeunea spp. L. anisophylla (A), L. cocoes (B), L. exilis (C), L. papilionacea (D), L. catanduana (E), and L. curviloba (F) observed by SEM. 'pa' indicates papillae, while 'ma' indicates mamillae
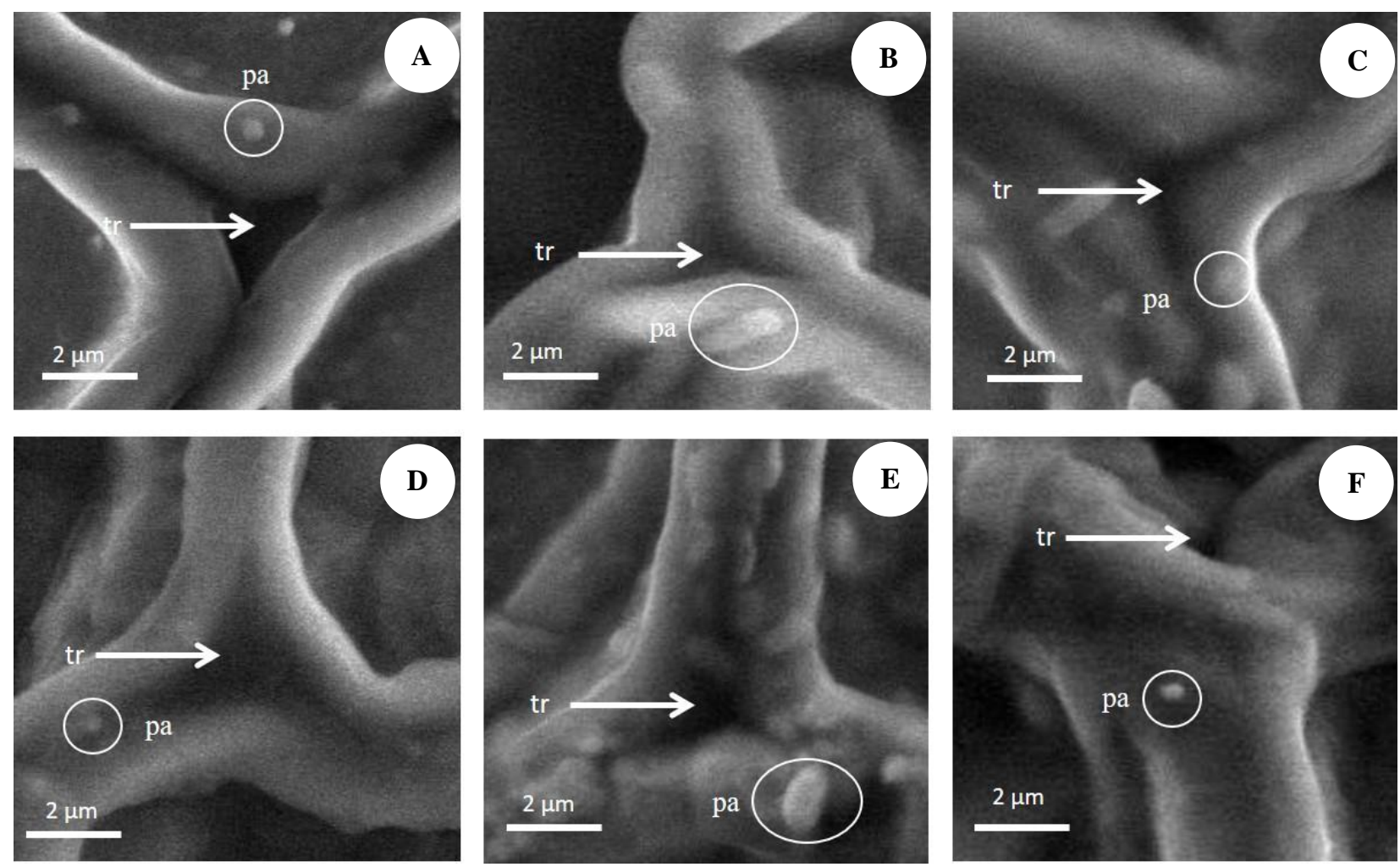

Figure 7. Visualization of the trigon of Lejeunea spp. L. anisophylla (A, A'), L. cocoes (B, B'), L. exilis (C, C'), L. papilionacea (D, D'), L. catanduana (E, E') and L. curviloba (F, F') observed by SEM. 'pa' indicates papillae, while 'ma' indicates mamillae. Trigon is depicted by the arrows ("tr"). 
Table 1. Laminal cell characters of six species of Lejeunea in UI Campus, Depok, Indonesia under SEM

\begin{tabular}{|c|c|c|c|c|c|c|c|c|}
\hline \multirow[t]{2}{*}{ Species } & \multicolumn{3}{|c|}{ Laminal cell wall surface } & \multirow[b]{2}{*}{$\begin{array}{c}\text { Texture } \\
\text { of cell } \\
\text { surface }\end{array}$} & \multicolumn{4}{|c|}{ Laminal cell surface } \\
\hline & $\begin{array}{l}\text { Texture of } \\
\text { cell wall }\end{array}$ & $\begin{array}{c}\text { Type of } \\
\text { ornamentation }\end{array}$ & $\begin{array}{c}\text { Cell wall } \\
\text { thickness } \\
(\mu \mathrm{m})\end{array}$ & & $\begin{array}{c}\text { Type of } \\
\text { ornamentation }\end{array}$ & $\begin{array}{l}\text { Ornamentation } \\
\text { length }(\mu \mathrm{m})\end{array}$ & $\begin{array}{l}\text { Number of } \\
\text { ornamentation } \\
\text { (per cell) }\end{array}$ & $\begin{array}{l}\text { Average size of } \\
\text { leaf cells }(\mu \mathrm{m})\end{array}$ \\
\hline L. anisophylla & $\begin{array}{l}\text { Slightly } \\
\text { rough }\end{array}$ & Papillae & $1.4-2.15$ & $\begin{array}{l}\text { Slightly } \\
\text { rough }\end{array}$ & Conical papillae & $1.1-2.0$ & $1-3$ & $\begin{array}{l}\text { L: } 17.14-20.02 \\
\text { W: } 18.57-21.98\end{array}$ \\
\hline L. cocoes & $\begin{array}{l}\text { Slightly } \\
\text { rough }\end{array}$ & Papillae & $1.08-1.19$ & $\begin{array}{l}\text { Slightly } \\
\text { rough }\end{array}$ & Simple papillae & $1.5-2.3$ & $1-3$ & $\begin{array}{l}\mathrm{L}: 11.24-12.56 \\
\mathrm{~W}: 11.20-13.05\end{array}$ \\
\hline L. exilis & $\begin{array}{l}\text { Slightly } \\
\text { rough }\end{array}$ & Papillae & $3.15-3.81$ & $\begin{array}{l}\text { Slightly } \\
\text { rough }\end{array}$ & Conical papillae & $1.1-3.2$ & $1-3$ & $\begin{array}{l}\text { L: } 15.37-18.54 \\
\text { W: } 14.55-16.78\end{array}$ \\
\hline L. papilionacea & $\begin{array}{l}\text { Slightly } \\
\text { rough }\end{array}$ & Papillae & $1.26-1.7$ & $\begin{array}{l}\text { Slightly } \\
\text { rough }\end{array}$ & Conical papillae & $0.7-1.8$ & $1-2$ & $\begin{array}{l}\text { L: } 14.08-20.18 \\
\text { W: } 10.15-11.40\end{array}$ \\
\hline L. catanduana & Rough & Papillae & $1.12-1.47$ & Rough & $\begin{array}{l}\text { Conical papillae } \\
\text { mamillae }\end{array}$ & $1.5-3.6$ & $1-4$ & $\begin{array}{l}\text { L: } 16.35-20.27 \\
\text { W: } 10.00-12.49\end{array}$ \\
\hline L. curviloba & $\begin{array}{l}\text { Slightly } \\
\text { rough }\end{array}$ & Papillae & $2.63-3.39$ & $\begin{array}{l}\text { Slightly } \\
\text { rough }\end{array}$ & Conical papillae & $1.7-2.1$ & $1-3$ & $\begin{array}{l}\text { L: } 10.27-16.54 \\
\text { W: } 12.29-12.35\end{array}$ \\
\hline
\end{tabular}

To conclude, according to the observation by the SEM, six species of Lejeunea in the Universitas Indonesia Campus could successfully be distinguished based on the ultrastructure characters of the laminal cell surface. Altogether, the results suggested that the ultrastructure characteristic might be potential to be used to differentiate the Lejeunea.

\section{ACKNOWLEDGEMENTS}

We are grateful to the Indonesian Ministry of Research, Technology, and Higher Education for the PDUPT Grant with the contract number of NKB1587/UN2.R3.1/HKP.05.00/2019 to A.D. We are very grateful to Research and Development Directorate, Universitas Indonesia, for the support on the use of the Integrated Laboratory and Research Center, Universitas Indonesia during sample preparation.

\section{REFERENCES}

Ariyananda A. 2015. Liverworts and Mosses Diversity in the UI Urban Forest. [Hon. Thesis]. Universitas Indonesia, Depok. [Indonesian]

Câmara PEAS, Kellogg EA. 2010. Morphology and Development of Leaf Papillae in Sematophyllaceae. The Bryologist 113 (1): 22-33. DOI: 10.1639/0007-2745-113.1.22.

Choudhary OP, Priyanka. 2017. Scanning electron microscope: advantage and disadvantage in imaging component. Intl J Curr Microbiol Appl Sci 6 (5): 1877-1882.

Dwiranti A, Masri F, Rahmayenti DA, Putrika A. 2019. The effects of osmium tetroxide post-fixation and drying step on leafy liverwort ultrastructure study by scanning electron microscopy. Microsc Res Tech 6 (3): 1-6.

Gradstein SR. 2011. Guide to the liverworts and hornworts of Java Seameo Biotrop, Bogor. Gradstein SR, Kien-thai Y, Suleiman M, Putrika A, Apriani D, Yuniati E, Kanak FAG, Ulum FB, Wahyuni I, Wongkuna K, Lubos LC, Tam LT, Puspaningrum MR, Serudin MRPG. Zuhri M, Min NA, Junita N, Pasaribu N, Kornochalert S. 2010. Bryophytes of Mount Patuha, West Java, Indonesia. J Taxon
Bot Plant Soc Ecol 13(2): 95-220.

Haerida I. 2017. Liverworts of Bali, Indonesia, with new records to the island. Gard Bull Sing 69(1): 81-87.

Haerida I, Gradstein SR. 2011. Liverworts and hornworts of Mt. Slamet Central Java (Indonesia). Hikobia 16: 61-66.

Konrat AH, Söderström L, Mutke J, Renner M, Gradstein SR, Engel J, Zhu RL, Pickering J. 2008. Early land plants today: global patterns of liverwort diversity, distribution, and floristic knowledge. In: Mohamed H, Baki BB, Nasrulhaq-Boyce A, Lee PKY (eds.). Bryology in the New Millennium. Institute of Biological Sciences University of Malaya and International Association of Bryologists, Kuala Lumpur.

Kou J, Feng C, Bai X, Chen H. 2014. Morphology and taxonomy of leaf papillae and mammillae in Pottiaceae of China. J Syst Evol 52 (4): 521-532. DOI: 10.1111/jse.12074.

Lee GE. 2013. Systematic of Revision of the Genus Lejeunea Lib. (Marchantiophyta: Lejeuneaceae) in Malaysia. Cryptogamie Bryologie 34 (4): 381-484.

Lee GE, Gradstein SR. 2013. Distribution and habitat of the Malaysian species of Lejeunea (Marchantiophyta: Lejeuneaceae), with description of Lejeunea tamaspocsii sp. nov. Pol Bot J 58 (1): 59-69. DOI: $10.2478 / \mathrm{pbj}-2013-0007$.

Lee GE, Gradstein SR, Latiff A. 2011. Toward a revision of Lejeunea (Lejeuneaceae) in Malaysia. Gard Bull Sing 63 (1\&2): 163-173.

Lee GE, Gradstein SR, Latiff A. 2014. New and neglected morphological features in the taxonomy of Asian Lejeunea (Marchantiophyta). Pol Bot J 59 (1): 31-36. doi: 10.2478/pbj-2014-0010.

Lee GE. 2020. Morphological data of Genus Lejeunea (Marchantiophyta: Lejeuneaceae) in the Malesian region. Data in Brief 28: 1-28. DOI: 10.1016/j.dib.2019.104958.

Lee JT, King. 2012. SEM Sample preparation for cells on 3D scaffolds by freeze-drying and HMDS. Scanning 34 (1): 12-25. DOI: $10.1002 /$ sca.20271.

Putrika A, Wijaya SK, Dwiranti A, Atria M. 2020. Species diversity and of epiphyte leafy liverworts and new record of Java. Floribunda 6 (4): 133-140. [Indonesian].

Siregar ES, Pasaribu N, Kahirani. 2020. The liverwort family Lejeuneaceae (Marchantiophyta) of Mount Lubuk Raya, North Sumatra, Indonesia. Biodiversitas 21: 2767-2776. DOI: 10.13057/biodiv/d210653.

Wijaya SK, Putrika A., Dwiranti, A, Atria M. 2019. Oil bodies variation in ephypitic leafy liverworts at Universitas Indonesia, Depok. AIP Conf Proc 2168: 020076. DOI: 10.1063/1.5132503

Zhu R-L, Lu C-H, Shu L. 2018. Additions and corrections for liverworts and hornworts of Singapore. Philippines J Syst Biol 2 (1): 12-21. 